Grisel Ponciano

Kansas State University, Manhattan

Hiromichi Ishihara and Shinji Tsuyumu

Shizuoka University, Shizuoka, Japan

Jan E. Leach

Kansas State University, Manhattan

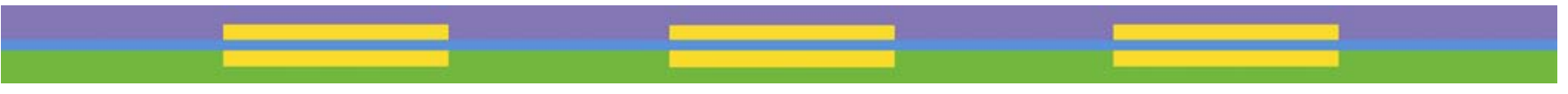

\title{
Bacterial Effectors in Plant Disease and Defense: Keys to Durable Resistance?
}

To develop effective strategies to protect crops from diseases, it is important to understand the molecular basis of the pathogen and host plant interactions that result in disease or resistance. Much past research emphasis was placed on identifying pathogen genes and proteins involved in triggering defense, i.e., the avirulence genes that interact, in a gene-for-gene manner, with plant disease resistance (R) genes (22). Mutational analysis of some avirulence genes demonstrated that many encoded essential components of pathogenicity or provided a selective (fitness) advantage to the pathogen in the absence of a corresponding plant resistance gene $(52,84)$. Thus, the effectors function in both avirulence and pathogenicity, with their primary function likely being the promotion of disease (Table 1). Research is now directed at identifying and understanding the functions of bacterial pathogen effectors, which are defined as bacterial-produced proteins or compounds that contribute to an induced plant response, either disease or resistance.

Our understanding of effector function has advanced rapidly with the identification of interacting partners from the host plants. With the cloning of both bacterial and plant gene partners, we have benefited from increasing information on key structural features of the genes and their products, the locations of the proteins during critical phases, and most recently, on the intermolecular interactions in which these proteins are involved. Functional analyses

Corresponding author: Jan E. Leach, Department of Plant Pathology, 4024 Throckmorton Plant Sciences, Kansas State University, Manhattan 66506-5502; E-mail: jeleach@ksu.edu

Publication no. D-2003-0909-01F

(C) 2003 The American Phytopathological Society of the pathogen effector genes and their products have provided new insights into both how bacteria cause disease and induce resistance. One of the many lessons learned from these advances is that the early models predicting that gene-for-gene interactions involve elicitor-receptor interactions between the bacterial effector and plant resistance gene products don't adequately address the nuances and complexities now being revealed.

The demonstration of roles for effector genes in both avirulence and pathogenicity also has renewed interest in the relationship between importance of effector genes in pathogen fitness and durability of plant $\mathrm{R}$ genes (52). Gene-for-gene resistance governed by $\mathrm{R}$ genes is frequently rendered ineffective through the mutation or loss of effector gene avirulence function. Flor $(26,27)$ first suggested that easily mutated avirulence genes in pathogen populations are less critical to pathogenic fitness than rarely mutated genes. The logical extension of this is that the $\mathrm{R}$ gene recognizing these critical avirulence effector genes might be more durable because the pathogen harboring these changes may suffer reduced competitive or fitness advantage in the plant and in the field $(27,52)$. The ability to predict durability of $\mathrm{R}$ genes would be of tremendous use to breeding programs, but until recently, our understanding of effector genes and the tools to monitor changes in these genes in field populations were insufficient to evaluate the concept. With the identification and molecular characterization of effector genes with fitness value, experimental studies to evaluate this concept are now emerging and are driving new strategies to create plant varieties with longer lasting resistance.

In this treatise, we first discuss the current models describing how bacterial effectors are delivered to the host plant cell and the structural features and activities that are important to induction of disease and resistance. We focus on the effectors delivered by the type III secretion system (TTSS) since most of the known avirulence effectors are secreted through this pathway. In the latter sections, we discuss how analysis of these effectors has provided insights into their evolution in field populations and has led to an understanding of their relationships to plant $\mathrm{R}$ gene durability.

\section{Mechanisms to Deliver Bacterial Effectors to Plant Cells}

For a pathogen to survive and multiply, it produces effector molecules to obtain nutrients from its host plant and cultivate the right environment in which to establish infection. Phytopathogenic bacteria use a number of secretion pathways to deliver effector molecules, either into the intercellular spaces or even directly into the host cells. These pathways vary in their complexity for delivery of the effectors (68). The complexity of the pathways is based on the number of proteins involved in the assembly of a channel or pore formed between the bacteria inner and outer membranes and through which the effectors are transported from the cytosol to the outside of the bacterium. There are four basic types of secretion pathways. Type I and II pathways secrete proteins to the supernatant or host intercellular spaces, whereas type III and IV pathways can deliver proteins or nucleic acids directly into the host cell (Fig. 1). The type I pathway is structurally the simplest; it allows direct secretion of effectors from the bacteria cytosol to the external environment. Examples of plant pathogen effectors secreted via the type I pathway are proteases and lipases from the soft-rot pathogen Erwinia chrysanthemi $(62,89)$. 
Table 1. Pathogenicity functions of effector genes from some plant pathogenic bacteria

\begin{tabular}{|c|c|c|c|}
\hline Pathogen & Gene & Pathogenicity function & Reference \\
\hline Erwinia amylovora & $d s p E F$ & 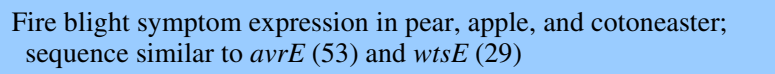 & $(11)$ \\
\hline Pseudomonas syringae pv. maculicola & avrRpml & Water-soaked symptom expression and bacterial multiplication & (66) \\
\hline \multirow[t]{3}{*}{ P. syringae pv. phaseolicola } & avrPphF & $\begin{array}{l}\text { Water-soaked symptom expression and bacterial multiplication } \\
\text { in bean and soybean }\end{array}$ & (80) \\
\hline & virPphA & Water-soaked symptom expression in bean & (44) \\
\hline & avrPphC & Blocks avirulence function of $a v r P p h F$ on Canadian Wonder bean & $(44,88)$ \\
\hline \multirow{4}{*}{ P. syringae pv. tomato } & avrA & Symptom expression and bacterial multiplication & $(54)$ \\
\hline & avrE & Symptom expression and bacterial multiplication & (54) \\
\hline & avrPto & Aggressiveness and bacterial multiplication in tomato & $(17,70)$ \\
\hline & avrRpt2 & Aggressiveness and bacterial multiplication in tomato & $(19)$ \\
\hline Xanthomonas axonopodis pv. citri & pthA & Intercellular growth and induction of cankers in citrus & (74) \\
\hline \multirow[t]{2}{*}{$X$. campestris pv. malvacearum } & avrb6 & Water-soaked symptom expression in cotton & (87) \\
\hline & $p t h N$ & Water-soaked symptom expression in cotton & $(16)$ \\
\hline \multirow[t]{3}{*}{$X$. campestris pv. vesicatoria } & $a v r B s 1$ & Survival in soil and dead leaf tissue & $(59)$ \\
\hline & avrBs2 & Aggressiveness and bacterial multiplication in pepper & (47) \\
\hline & avrBs3 & Mesophyll cell hypertrophy in different solanaceous plants & (57) \\
\hline \multirow[t]{2}{*}{ X. oryzae pv. oryzae } & avrxa5 & Lesion length and bacterial multiplication in rice & (5) \\
\hline & $a v r X a 7$ & Aggressiveness, lesion length, and bacterial multiplication in rice & (5) \\
\hline
\end{tabular}

The type II pathway is composed of a more complex secretion structure, and two steps are required for secretion of an effector: (i) transport to the periplasm (the space between the inner and outer bacterial membranes), and (ii) secretion across the outer membrane. Transport into periplasm requires an $\mathrm{N}$-terminal signal sequence, and during transfer to the periplasm, the protein is processed by a signal peptidase. The intermediate location in the periplasm allows proper folding of the effector before it is secreted (18). Pathogen effectors involved in cell wall degradation, such as pectate lyase, polygalacturonase, and cellulase from Erwinia and Xanthomonas species, are secreted by the type II pathway $(7,64,68)$.

The type III (also known as TTSS for type three secretion system) and type IV secretion pathways use complex structures similar to flagella (type III; 9) and conjugation structures (type IV; 20) to interact with the eukaryotic host cells and deliver their effectors. The type IV pathway is best known from studies on Agrobacterium tumefaciens. This pathway is the only secretion pathway described to translocate both proteins and nucleic acids. For example, the VirD2/T-DNA nucleoprotein complex is delivered through the type IV pilus from A. tumefaciens directly into the plant cell (21).

The TTSS has been widely studied because it is present in disease-causing bacteria of mammals and plants and is generally not found in their nonpathogenic counterparts $(14,15,24,43)$. The genes encoding the TTSS are called the hrp (hypersensitive response and pathogenicity) genes in phytopathogenic bacteria. The hrp genes are usually arranged in clusters and are located in pathogenicity islands (PAIs), which are discrete regions that vary in $\mathrm{G}+\mathrm{C}$ content from the overall genome and are flanked

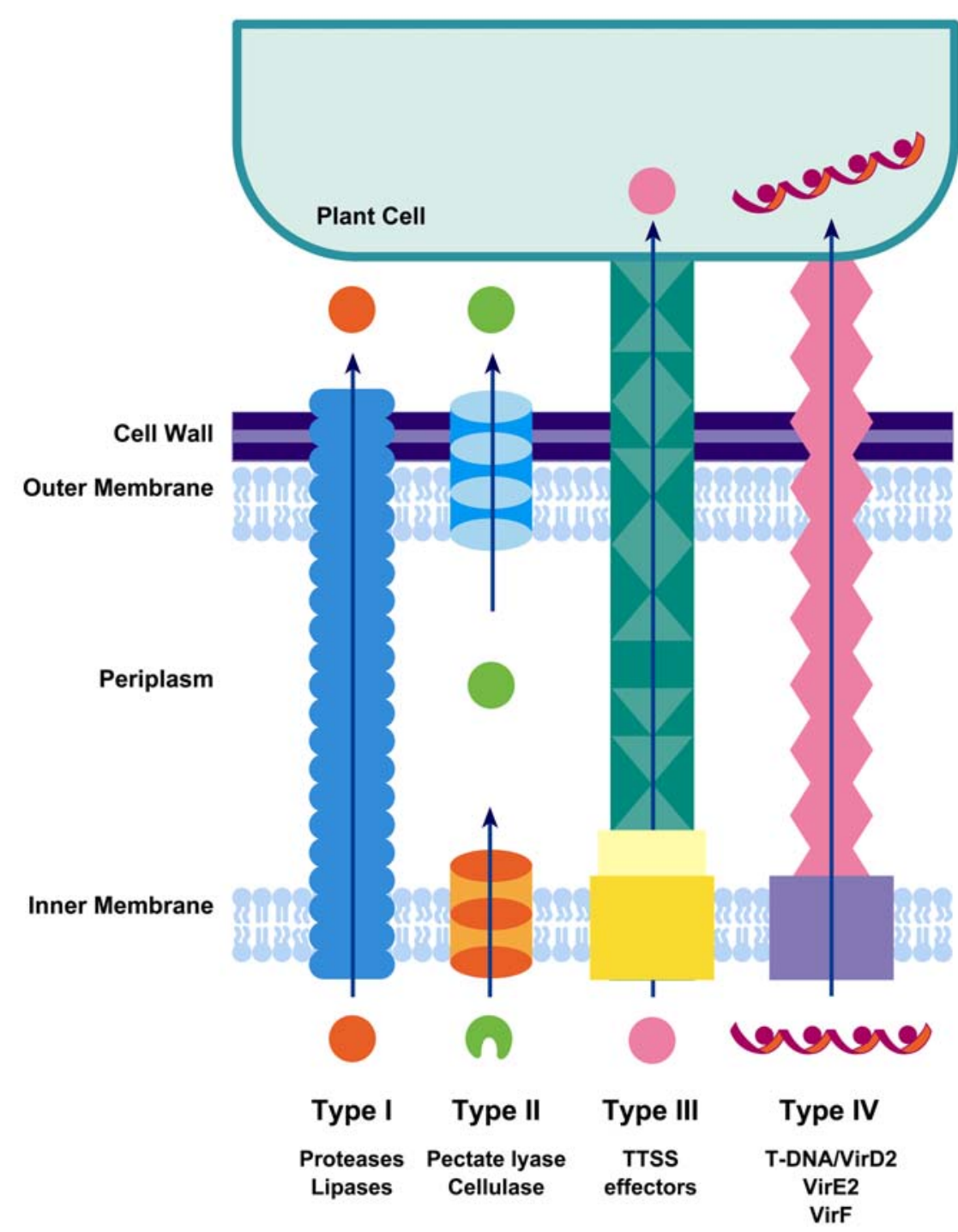

Fig. 1. Gram-negative phytopathogenic bacteria use four major pathways to secrete effectors (type I and II) to the intercellular spaces, or directly translocate effectors (type III and IV) into the plant cell. The effectors are pathogen-produced proteins that alter the plant cell or its environment to cause disease or to trigger defense. Specific examples of effectors transported by each pathway are indicated. 
by insertion sequences, bacteriophage genes, and transposable elements (33). These features suggest that PAIs originated from other species, and that they were acquired by horizontal gene transfer. The newly acquired genetic material may confer new pathogenic and fitness traits to the bacteria (37). The hrp genes encode proteins that either regulate synthesis or assembly of the TTSS, are structural components of the TTSS, or are extracellular proteins (e.g., harpins) secreted by the TTSS (33). The hallmark characteristic of the TTSS structure, a needle-like protruding structure with a channel along which proteins travel, is its resemblance to bacteria flagella (9), both at the structural and functional level. Like the type I pathway, secretion of effector proteins via the TTSS is a one-step process with no intermediates in the periplasm. Some effectors require small

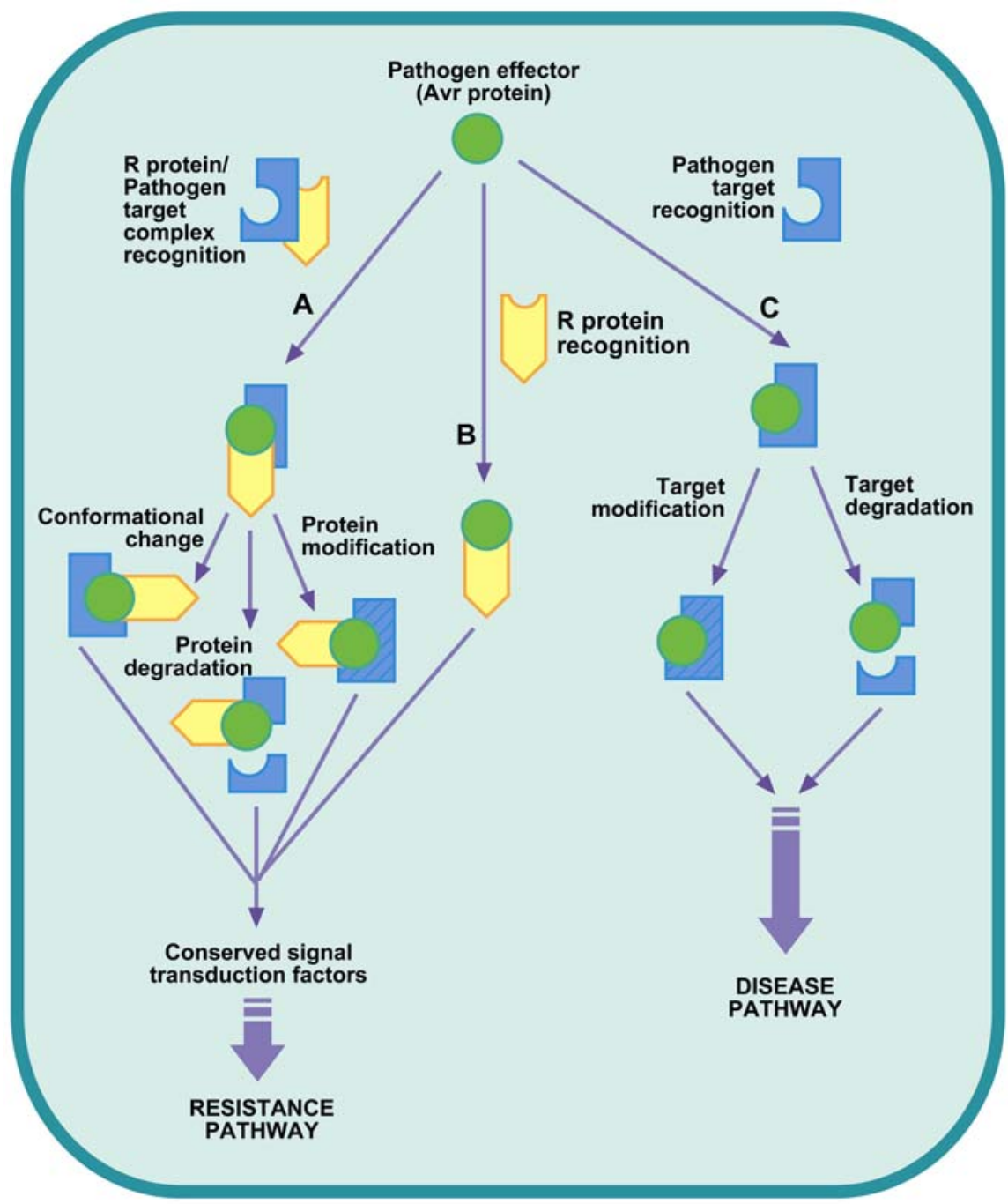

Fig. 2. Some type III secretion system (TTSS) effectors modify a host target protein inside the plant cell promoting disease (C) or triggering resistance (A,B). The modification, which may be a conformational change, proteolytic cleavage, or phosphorylation of the target protein, is detected by the bound resistance gene product $R$ (A). The effector also may interact directly with the $R$ protein to trigger resistance $(B)$. The conserved signal transduction factors are proteins present in both monocots and dicots that are essential for signaling the resistance response (41).

\section{Roles of TTSS Effectors in Pathogenicity and Resistance}

Although the mechanisms are not clear, TTSS effector proteins are predicted to (i) stimulate an increase in the $\mathrm{pH}$ and nutrient content of the plant apoplast, making the apoplastic fluids more hospitable for bacterial multiplication $(2,3)$, (ii) activate the host defense responses through recognition by a corresponding host $\mathrm{R}$ protein (avirulence function; 12,49), (iii) inhibit the activation of host defense responses that are signaled by other TTSS avirulence effectors $(44,65,67)$, or (iv) inhibit basal plant resistance mechanisms $(38,80)$. Most of the over 40 known bacterial TTSS effectors were originally identified by their avirulence function in gene-for-gene interactions $(12,52)$, and as a consequence, most research has focused on understanding how these proteins interact with plant proteins to activate defense responses (58). Such plant defense responses are characterized by many cellular and molecular events, including the formation of active oxygen species, defense gene induction, and in many cases, a rapid, localized cell death called the hypersensitive response (HR). Activation of the HR, which is a genetically controlled and regulated process similar to programmed cell death (35), is frequently used in studies to indicate activation of defense responses by effectors.

Since some TTSS effector proteins cause both disease and resistance phenotypes, studies into their roles in resistance have also identified possible plant virulence targets for the effector proteins. Interestingly, these plant virulence targets may or may not be the plant $\mathrm{R}$ gene product. Following, we summarize some of the current and simplest interpretations of how effectors function in disease and resistance.

Modification of plant interactors. Some TTSS effectors modify plant target proteins inside the plant cell to stimulate either the activation of defense (Fig. 2A and $\mathrm{B}$ ) or the induction of disease (Fig. 2C). Interactions involving TTSS effectors from Pseudomonas syringae and their target protein from Arabidopsis thaliana provide excellent examples of these possibilities. P. syringae TTSS effectors AvrPphB and AvrRpt2 are cysteine proteases whose proteolytic activity is essential for elicitation of the HR (4,71, Notes 1 and 2). HR elicitation by AvrRpt2 in Arabidopsis plants containing the corresponding resistance gene product, RPS2, requires cleavage of a plant membrane-bound target protein called RIN4. RIN4 is complexed with the RPS2 resistance protein, and cleavage of RIN4 by AvrRpt2 protease results in the release of RIN4 from the complex (protein degradation in Fig. 2A). Change in the overall structure of the complex is thought to be detected by RPS2, and thus the RPS2-mediated resistance response is signaled. Interestingly, two 
other bacterial effectors from $P$. syringae, AvrRpm1 and AvrB, which are not proteases, also use RIN4 as a plant target, but they signal resistance through another $\mathrm{R}$ protein, RPM1 (56), and by a different protein modification mechanism. AvrB and AvrRpm1 TTSS effectors induce phosphorylation of RIN4. The phosphorylation of RIN4 is detected by RPM1, and this activates the RPM1-mediated resistance response (protein modification in Fig. 2A).
The above studies show that the TTSS effector modification of a plant target protein is required for avirulence function. The requirement for modification by proteolytic cleavage or phosphorylation in the pathogenicity functions has not been determined, but it is speculated for AvrRpt2, again through interaction with the target RIN4 (4). Mackey et al. (55) suggest that the "normal" function of RIN4 may be to activate basal defense in plants. Cleavage of RIN4 by effector AvrRpt2 protease in the absence of any $\mathrm{R}$ proteins is predicted to suppress these basal defense responses and, therefore, result in enhanced susceptibility. Indeed, in the absence of RPS2 (rps2 plants), cleavage of RIN4 by AvrRpt2 leads to more pathogen growth in the tissues $(55,56)$. Thus, RIN4 is the virulence target of AvrRpt2, and its proposed function in the plant cell is to regulate a basal level of defense. RIN4 may also function

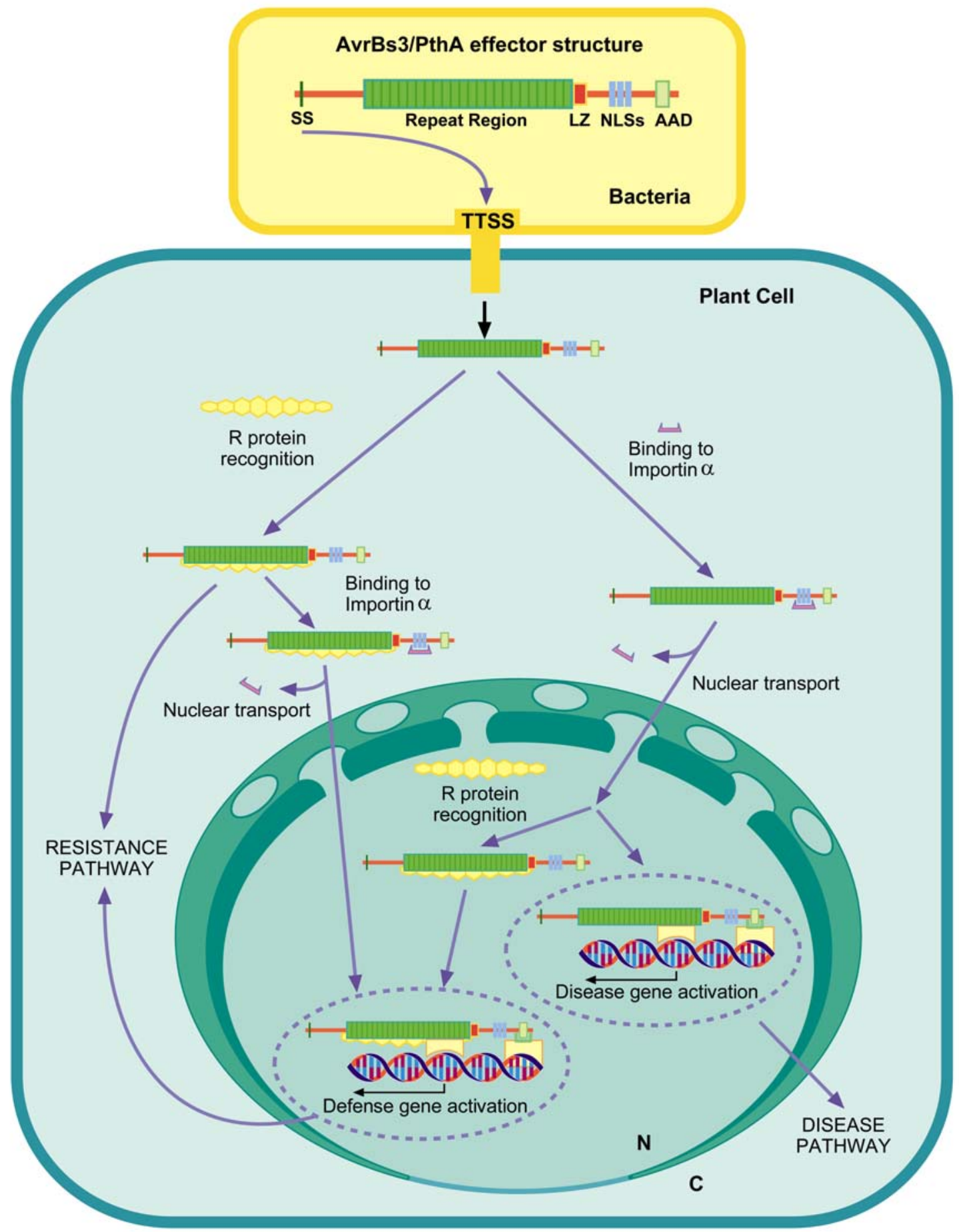

Fig. 3. Model showing speculated pathways leading to resistance involving AvrBs3/PthA effectors. Some effector proteins in this family are transported to the plant cell nucleus where they may activate transcription of disease and/or defense response genes. It is not known where recognition of the AvrBs3/PthA protein by plant resistance (R) proteins occurs, i.e., in cytoplasm or nucleus. SS, secretion signal; LZ, imperfect leucine zipper; NLSs, nuclear localization signals; AAD, acidic activation domain; TTSS, type III secretion system; $\mathrm{N}$, nucleus; $\mathrm{C}$, cytosol. 
in plant development because inactivation of RIN4 resulted in a dwarf phenotype in Arabidopsis (56).

RIN4 is likely a critical intermediary protein in plant-pathogen interactions in Arabidopsis because several TTSS effector proteins, including AvrRpt2, AvrRpm1, and AvrB, all interact with and modify this plant protein. It is particularly intriguing that pathogenic bacteria have evolved effectors with no sequence relationships that all target RIN4, and that plants have evolved different $\mathrm{R}$ proteins to monitor the condition of this target protein.

Other effectors, such as AvrBst (60) and AvrRxo1 (B. Y. Zhao, E. Ardales, S. Hulbert, and J. Leach, unpublished) from Xanthomonas species, harbor sequences consistent with protease catalytic domains; however, whether or not they actually function as proteases has not been determined. Identification of plant virulence and avirulence targets for these and other effectors is an important step in addressing how general TTSS effector modification of host target proteins is in plant disease and defense.

Possible transcriptional activation of plant defense or disease response genes. The AvrBs3/PthA family is a group of highly conserved TTSS effectors prevalent in the genus Xanthomonas (30). The functions of these effectors in the host plant have been deduced from their unique protein structure (Fig. 3 and Table 2), which is composed of (i) a central region of multiple, nearly identical repeated sequences of 34 amino acid residues, (ii) three nuclear localization signals (NLSs) in the carboxyl terminus, and (iii) an acidic activation domain (AAD) also in the carboxyl terminus. Based on the last two structures, the NLSs and AAD, these effectors are predicted to function in the plant nucleus (for details see references on Table 2). Indeed, several family members were demonstrated to locate to the plant nucleus $(78,81,86)$ and, in one case, to bind to DNA in vitro (85), which is consistent with a role in gene activation. Mutagenesis of both NLSs and AAD structures abolishes defense responses and reduces the ability of the pathogen to cause disease in various plant-pathogen interactions. One family member, AvrBs3 from X. campestris pv. vesicatoria, activates host genes and causes a characteristic hypertrophy in pepper; these activities require the repeats, NLSs and AAD (57). Whether these or other AvrBs3/PthA-like effectors directly activate plant defense genes remains unknown.

It is also unclear where, when, and how recognition of the AvrBs3/PthA effectors by the corresponding $\mathrm{R}$ proteins takes place. That is, it is not yet known if recognition for resistance takes place in the cytosol or nucleus, or if it is dependent or independent of nuclear localization. At least for one member of the family, AvrBs4 from $X$. campestris pv. vesicatoria, HR-mediated resistance in tomato plants with the corresponding Bs4 resistance gene is independent of nuclear localization (6). Progress in elucidating the function of the complex AvrBs3/PthA-like effectors will be expedited as more host interactors are identified.

Inhibition of defense response induction. Bacterial TTSS effectors can function to prevent host recognition and/or block activation of host defense responses $(65,67,80)$. For example, the TTSS effector protein VirPphA from $P$. syringae pv. phaseolicola is proposed to interfere with signal transduction leading to the HR (44; pathogen effector 2 in Fig. 4). Delivery of the VirPphA from the bacteria to bean allows the pathogen to avoid HR-based resistance and to colonize the plants, even if the same pathogen also delivers a separate effector (pathogen effector 1 in Fig. 4) that is recognized by a host resistance gene product.

Interference with HR signaling is a plausible function for a virulence effector. In fact, this is the case for AvrPtoB, an effector protein from $P$. syringae pv. tomato that shares low sequence similarity to AvrPto. AvrPtoB inhibits HR-related programmed cell death in Nicotiana benthamiana (the signaling components of the tomato Ptomediated resistance are conserved in $N$. benthamiana), thereby allowing the pathogen to colonize and cause disease (1). Interestingly, AvrPtoB is similar to VirPphA (57\% identity at the protein level) and is widely distributed among several genera of phytopathogenic bacteria, including Xanthomonas, Erwinia, and Pseudomonas. This suggests the presence of a common structural feature for a virulence effector in plant-pathogenic bacteria and has great implications in plant disease. How AvrPtoB interferes with the HR is not known, but its interference occurs downstream of $\mathrm{R}$ protein recognition.

Recent work suggests that bacterial effectors encoded by avrPto and genes of the avrBs3/pthA family (apll from $X$. axono- podis pv. citri [46] and avrXal0 from $X$. oryzae pv. oryzae [42]) suppress plant defense responses (T. Fujikawa, H. Ishihara, and S. Tsuyumu, unpublished). For these studies, a strain of the saprophytic bacteria $P$. fluorescens expressing the TTSS and an effector from $P$. syringae pv. syringae was used; this strain elicits a nonspecific HR in tobacco. When this strain was used to deliver Apl1, AvrXa10, or AvrPto effector proteins to tobacco cells, the HR and other defense responses were suppressed. These bacterial effector proteins may be functioning in ways analogous to fungal suppressors of defense responses such as the one isolated from spore germination fluid of the pea fungal pathogen Mycosphaerella pinodes (72). This fungal suppressor retards defense responses in pea induced by a fungal nonspecific glycoprotein elicitor, but it functions as an elicitor of defense responses in cowpea (a nonhost plant). The fungal suppressor specifically inhibited NTPase (nucleoside triphosphatase) in pea cell walls, but not in cowpea walls. Interestingly, the bacterial Avr effectors delivered by $P$. fluorescens also specifically inhibit the NTPase in tobacco cell walls (T. Fujikawa, H. Ishihara, and S. Tsuyumu, unpublished)

Another mechanism by which TTSS effectors may suppress defense responses was recently described for $P$. syringae pv. tomato-A. thaliana interactions (38). The $P$. syringae pv. tomato strain DC 3000 with a functional TTSS suppresses expression of a large set of Arabidopsis genes that encode putatively secreted cell wall and defense proteins such as extensins, hydroxyproline-rich proteins, germin-like proteins, lipid transfer proteins, and phosphatases. This suppression is caused by AvrPto that is translocated by the TTSS because AvrPto-expressing transgenic lines of Arabidopsis exhibited down regulation of the same cell wall and defense protein genes. Interestingly, extensins and hydroxyproline-rich proteins are components of defense response cell wall appositions

Table 2. Known functions of various domains found in AvrBs3/PthA family members

\begin{tabular}{|c|c|c|}
\hline Domain & Function & Reference \\
\hline Secretion signal, SS & $\begin{array}{l}\text { Signal required for protein secretion } \\
\text { through the type III secretion system }\end{array}$ & (78) \\
\hline Repeat region & $\begin{array}{l}\text { Essential for avirulence and pathogenicity. } \\
\text { Biochemical function unknown }\end{array}$ & $(40,57,85)$ \\
\hline $\begin{array}{l}\text { Imperfect leucine } \\
\text { zipper, LZ }\end{array}$ & $\begin{array}{l}\text { Biochemical function unknown. LZ motifs } \\
\text { are involved in protein-protein and } \\
\text { protein-DNA interactions }\end{array}$ & (30) \\
\hline $\begin{array}{l}\text { Nuclear localization } \\
\text { signals, NLSs }\end{array}$ & $\begin{array}{l}\text { Essential for avirulence and pathogenicity } \\
\text { for most gene family members. Directs } \\
\text { protein to plant nucleus. Second NLS of } \\
\text { AvrBs3 binds to importin } \alpha\end{array}$ & $\begin{array}{l}(6,32,77,78,81,85, \\
86,90)\end{array}$ \\
\hline $\begin{array}{l}\text { Acidic activation } \\
\text { domain, AAD }\end{array}$ & $\begin{array}{l}\text { Essential for avirulence and pathogenicity. } \\
\text { Activates transcription of a reporter gene } \\
\text { in plant transient assays and in yeast cells, } \\
\text { and activates host gene expression } \\
\text { leading to pathogenic phenotype }\end{array}$ & $(57,77,85,90)$ \\
\hline
\end{tabular}


called papilla that are initiated by bacterial pathogens lacking a functional TTSS as well as by saprophytes $(8,13)$. These results suggest that TTSS effectors are suppressors of cell wall-based plant defense (Fig. 4).

In the absence of a functional TTSS, the cell wall-based defense is induced. $\mathrm{Mu}-$ tants of $P$. syringae pv. tomato DC 3000 bacteria that are deficient in the TTSS induce significantly more callose deposition in Arabidopsis compared with wild type DC3000 (38). Callose is a major component of papilla. Again, this response can be suppressed by AvrPto, because AvrPtoexpressing transgenic Arabidopsis plants showed low levels of callose deposition.

The fact that AvrPto suppresses both a cell wall-based defense (38) and an HRbased defense described above (T. Fujikawa, H. Ishihara, and S. Tsuyumu, unpublished) suggests that this TTSS effector uses different mechanisms of suppression. This raises the questions of how an effector could evolve with two different mechanisms of suppression or whether both of the mechanisms are the same or interconnected. In addition, while AvrPto suppresses the cell wall-based defense response as described above, this suppression does not likely require interaction with the $\mathrm{R}$ protein Pto, a serine/threonine protein kinase (17,70). Avirulence function, on the other hand, does require physical interaction with Pto in the plant cytoplasm $(69,79)$. This demonstrates that, at least in some cases, the plant interactors for disease may be different than those for activation of defense.

\section{Lessons Learned through Analysis of TTSS Effectors}

The contributions of effector genes to pathogen avirulence and pathogenicity were determined by using gene-specific knockout mutants in the effector genes or by comparing naturally occurring variants of the genes isolated from field populations $(31,52)$. Several important points relevant to the dual roles of effector genes can be derived from these studies. First, as discussed above, the molecular basis for how TTSS effector genes contribute to disease or resistance may vary, but there are commonalities that are emerging. For example, modification of a host target protein and detection of that modification by an $R$ protein have been found for more than one TTSS effector/host interaction. Suppression of host defense responses by TTSS effectors has been described for bacterial interactions with bean, Arabidopsis, tomato, and tobacco $(1,38)$.

Second, effector genes may contribute to different attributes of pathogenicity. In some cases, the effectors control intercellular multiplication $(5,74,75)$, whereas in other cases, the effectors control the ability of the bacteria to exit the intercellular spaces to the leaf surface (87). Such an increase in the release of bacteria to the leaf surface could have a major impact on the epidemic potential of the pathogen.

Third, not all effectors contribute measurably to pathogenicity, and those that do may have quantifiably different contributions. Mutations in avrXal0 from $X$. orzyae pv. oryzae (5) and avrBs3 from $X$. campestris pv. vesicatoria (81) did not cause a measurable loss in pathogen aggressiveness or bacterial multiplication in planta. On the other hand, the relative contributions of other avrBs3/PthA effectors to pathogenicity varied considerably $(5,87)$. Inactivation of some individual members of the avrBs3 family in X. campestris pv. malvacearum and $X$. oryzae pv. oryzae reduces disease symptom expression in cotton and rice, respectively. In both cases, the relative contribution by individual gene members varied. For example, the $X$. oryzae pv. orzyae with a mutation in the avrXa7 gene caused much shorter lesions than the strain with mutations in other avrBs3/pthA family members (5).

Fourth, redundancy of function may make it difficult to measure a pathogenicity function for a given gene (22). In some xanthomonads, there are many copies of members of the avrBs3/pthA gene family, and some of these contribute additively and redundantly to pathogenicity (87). In other cases, although the genes are redundant, the functions of those genes are not redundant, i.e., the pathogenicity function of the effector gene may be gene specific. In $X$. oryzae pv. oryzae mutants in avrXa7, the pathogenicity function could only be complemented by the $a v r X a 7$ gene; the $a v r X a 7$ mutant was not complemented by other highly related gene family members that also have a pathogenicity function such as avrxa5 or $a B 4.5$ (5).

Fifth, some of the structural requirements for pathogenicity and avirulence functions are distinct. In a few cases, sitedirected mutagenesis has allowed the separation of the pathogenicity and avirulence functions of effector genes. Strains of $P$. syringae containing AvrPto with single amino acid changes exhibited a loss of avirulence function, but not of pathogenicity function (70). The avirulence and pathogenicity functions of the AvrBs2 effector from $X$. campestris pv. vesicatoria have also been uncoupled (34).

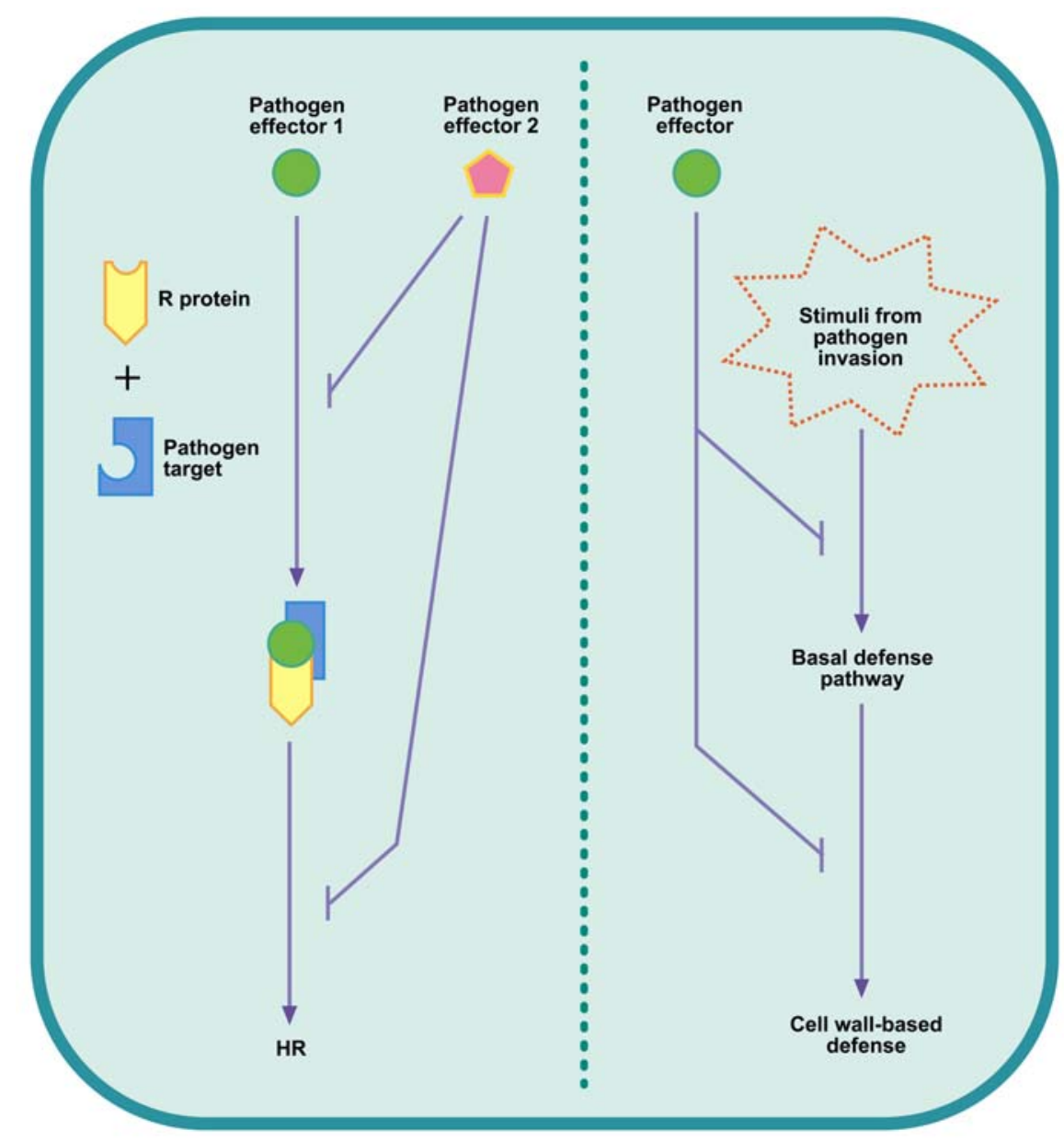

Fig. 4. Type III secretion system (TTSS) effectors can inhibit the basal plant resistance (right) or the resistance (R) protein mediated resistance (left). The exact mechanisms are not known and there is likely more than one mode of inhibition. HR = hypersensitive response. 
Sixth, to date, predicting the importance of effectors in pathogenicity and fitness from sequence structures has not been fruitful, mainly because few show similarities to known genes in databases. In a few cases, where effectors are related across pathovars, species, and even genera, and their roles in pathogenicity have been confirmed, their importance to pathogenic fitness has been speculated (48). For example, three related effectors, avrE from $P$. syringae pv. tomato, dspE from Erwinia amylovora $(10,11)$, and $w t s E$ from Pantoea stewartii subsp. stewartii (29), are critical for pathogenicity to each of the respective host plants, suggesting they may be important to pathogen fitness. As more commonalities in structure and function among effectors are observed and tested, it may be possible to predict the impact of loss of effector function on pathogen fitness.

Finally, the role of a particular effector gene in pathogenicity may vary in different bacterial genetic backgrounds. Inactivation of effector gene avrPto in P. syringae pv. tomato strain $\mathrm{T} 1$ affects pathogenicity, but in strain DC3000, inactivation of the avrPto gene has no effect (70). On the other hand, the pthA gene, which is required for virulence of $X$. axonopodis pv. citri to citrus plants, has different pathogenicity and avirulence functions when transferred to other xanthomonads (75).

\section{Population Level Analyses of Effectors}

Throughout the history of the use of single dominant $\mathrm{R}$ genes to control plant disease, we have faced "boom and bust" cycles, wherein the deployment of a new resistance gene controls disease for a limited time (boom), but then the pathogen population adapts to and overcomes the resistance (bust). The "bust" part of the cycle usually results from changes in the avirulence effector in the pathogen population, that is, mutations or loss of the bacterial effector genes that lead to loss of avirulence function and therefore breakdown in resistance. Many studies now have documented naturally occurring changes in effector genes that result in breakdown of resistance; these mutations can result from insertions, deletions, rearrangements, and loss of plasmids carrying the effector genes that function in avirulence $(25,34,48,50$, $76,83)$ Since effector genes function in pathogenicity, loss of effector gene function also can result in reduced pathogenicity or aggressiveness $(31,52,84)$. These mutations in effector genes that lead to reduced pathogenicity have been predicted to negatively impact pathogen fitness in field populations (52).

With increasing information on effector gene sequences and function, empirical tests of the prediction that mutations in

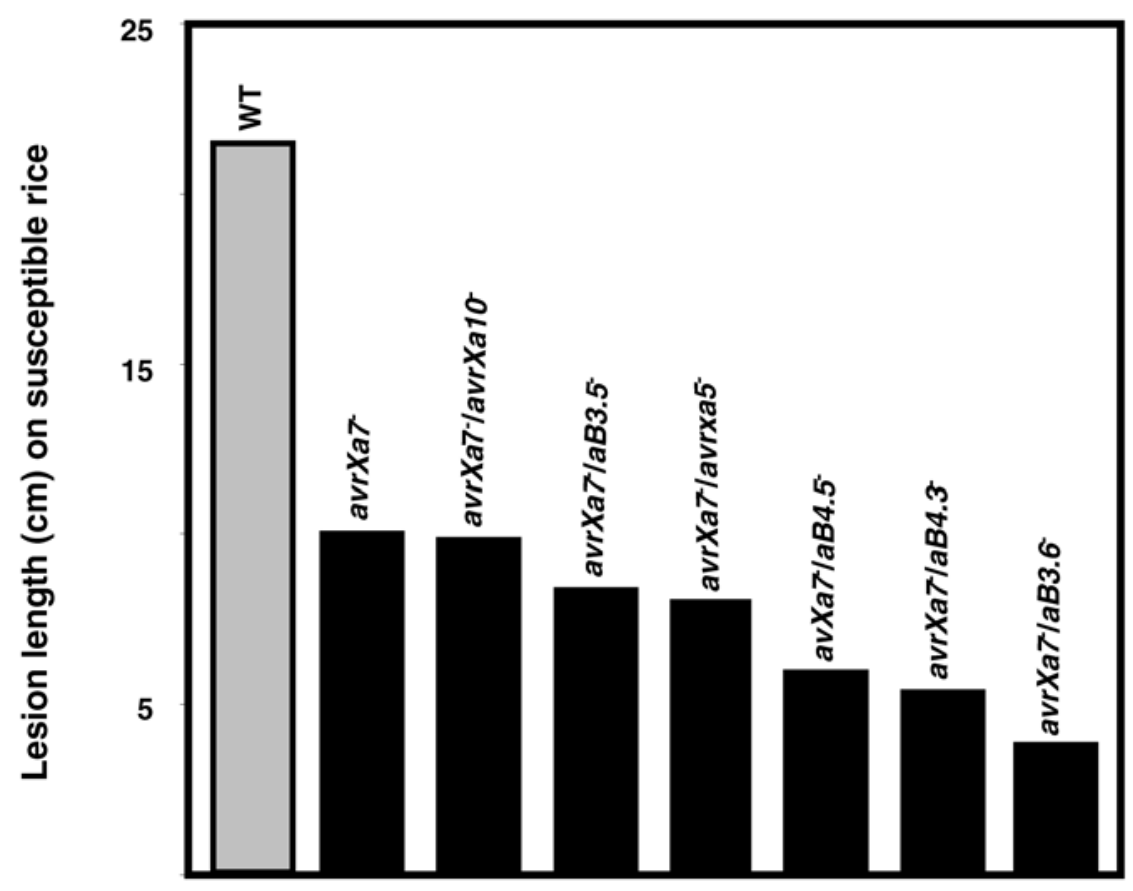

\section{avrBs3/pthA effector mutant}

Fig. 5. Contributions of individual Xanthomonas oryzae pv. oryzae avrBs3/pthA effector genes to pathogenicity in rice are different. Lesion lengths on susceptible rice caused by several $X$. oryzae pv. oryzae strains with the indicated avrBs $3 /$ pthA gene family member mutated. Mutations are in the background of wild-type strain PXO86. All double mutant strains harbor an insertion that inactivates the avrXa7 gene (avrXa7 $\left.{ }^{-}\right)$and a second insertion that inactivates the other family member. Figure adapted from Bai et al. (5). effector genes negatively impact pathogen fitness in field populations are possible. Vera Cruz et al. (83) established field plots to determine if the fitness cost associated with effector gene mutations was measurable in interactions between the bacterial blight pathogen, X. oryzae pv. oryzae, and rice. Previous laboratory studies had shown that $a v r X a 7$, the effector gene corresponding to the bacterial blight resistance gene $X a 7$, contributed to pathogen aggressiveness, whereas avrXa10, the effector gene corresponding to resistance gene $X a 10$, did not measurably contribute to aggressiveness (5; avrXa7lavrXa10 double mutant in Fig. 5). Based on these findings, Vera Cruz and co-workers predicted that $a v r X a 7$ but not $a v r X a 10$ would be important to pathogen fitness in the field.

The field experiments took place over 3 years (six cropping seasons) at two sites endemic for bacterial blight in the Philippines. $X$. oryzae pv. oryzae populations on rice lines near-isogenic for the bacterial blight resistance genes $\mathrm{Xa}$ and $\mathrm{Xa10}$ and the recurrent parent line IR24 were monitored. Neither Xa7 or Xa10 had been deployed in the Philippines prior to these experiments. Over the 3 years of the experiment, very little disease was observed on the rice line with $X a 7$, whereas severe disease was observed on the line with $\mathrm{Xa10}$ in the first year (83; Fig. 6). Clearly, loss of avrXa10 function was not imposing a significant fitness cost on the field population.

$X$. oryzae pv. oryzae strains virulent to $X a 7$ were detected during the course of the study (83). Based on the amount of disease they caused on plants with $X a 7$, these strains were divided into two groups, those that had completely lost $a v r X a 7$ avirulence function and those that had partially lost avirulence function. Strains that had completely lost avrXa7 avirulence function (virulent to rice with $\mathrm{Xa}$ ) were reduced in overall pathogenicity and did not increase, nor did they persist in the population. Sequence and complementation analyses confirmed that mutations in the avrXa7 gene resulted in the loss of both avirulence and pathogenicity functions of the effector protein. These results confirmed that the mutation in avrXa7 had imposed a significant cost on the overall fitness of the pathogen in the field.

The second group of strains isolated from the fields, i.e., those that show partial loss of $a v r X a 7$ avirulence function and little loss of aggressiveness to susceptible rice, are intriguing because they persisted and increased in the field population during the study, yet did not cause an epidemic on $\mathrm{Xa} 7$ rice (83). Significantly, continued samplings from one experimental site through 2002 show that this group of strains still persists, and yet still does not cause epidemic on $\mathrm{Xa} 7$ (K. Linholm, J. E. Leach, and C. Vera Cruz, unpublished). The strains in this group cause a range in 
lesion lengths on susceptible rice (no $\mathrm{Xa} 7$ gene), suggesting the possibility of many different mutations in the $a v r X a 7$ gene that impact avirulence and pathogenicity differently. Indeed, sequence analysis of the $a v r X a 7$ alleles from these mutants and reconstruction of some of the mutations in laboratory strains revealed a number of different changes in the avrXa7 allele, including point mutations and rearrangements (G. Ponciano, K. Linholm, J. Bai, C. Vera Cruz, and J. Leach, unpublished). These changes could explain the wide variation in pathogenicity exhibited by strains harboring the $a v r X a 7$ variants. Given that these strains persist and are increasing in the population, and that they are not as severely compromised in pathogenicity or fitness functions as the mutants with complete loss of avirulence function, it is intriguing that they have not yet caused an epidemic on $\mathrm{Xa7}$.

From a population perspective, the detection of field variants that harbor effector alleles with changes that impact avirulence but not pathogenicity or fitness functions is of most concern. Alleles from field-derived mutants of another avirulence effector, avrBs 2 from $X$. campestris pv. vesicatoria, were characterized to understand adaptation to the pepper resistance gene $B s 2$. In 20 characterized alleles, several variations were detected, including deletions, insertions, and point mutations (34). To test the effects of the mutations on avirulence and aggressiveness, isogenic strains of $X$. campestris pv. vesicatoria that contained chromosomal versions of several mutant alleles were generated. In some cases, the mutations resulted in the loss of avrBs2induced resistance on $B s 2$ pepper plants and abolition of avrBs2-mediated enhancement of fitness on susceptible plants. In other cases, the mutations led to minimal reduction of virulence function but either minimal or intermediate levels of avirulence function. Thus, the effector $a v r B s 2$ is evolving to decrease detection by the $B s 2$ gene while at the same time maintaining its virulence function. It will be interesting to determine if there is any other cost to fitness unrelated to pathogenicity that is imposed by these mutations in avrBs 2 , for example, a reduction in ability to survive outside the plant.

The avrBs $2 / B s 2$ study described above emphasizes the importance of knowing if fitness and avirulence functions can be separated by mutations to different parts of the effector structure and the frequency at which this can occur. This is particularly critical when trying to relate the genetics of pathogen fitness to $\mathrm{R}$ gene durability, that is, why the boom cycle lasts longer for some R genes than for others $(27,82)$. In the field study described by Vera Cruz and coworkers (83) that empirically tested the linkage between $\mathrm{R}$ gene durability and effector fitness, the resistance gene $(\mathrm{Xa} 7)$ that targeted a pathogen effector important for fitness (avrXa7) was not overcome by $X$. oryzae pv. oryzae variants. On the other hand, the resistance gene Xa10, which targeted a pathogen effector with no evidence of fitness contribution, was readily overcome. The authors suggested that $\mathrm{Xa} 7$ is more durable than XalO because the $a v r X a 7$ gene is more important for pathogen fitness than the avrXal0 gene. Now that many effector genes from many plant pathogens have been sequenced and characterized, the generality of the linkage of pathogen fitness to $\mathrm{R}$ gene durability can be tested.

\section{Summary and Future Perspectives}

Our understanding of the structure, location, and function of many bacterial pathogen effector genes and proteins and the nature of their interactions with plant virulence target and resistance proteins has progressed tremendously since the first avirulence gene was cloned in 1984 (73). With these advances, we have gained many insights into both how plants detect and respond to bacterial pathogens, and how The models that have developed from these studies have provided insights into new directed strategies for enhancing resistance not just to one pathogen, but to multiple pathogens. For example, knowing that RIN4 (or its homologs in other species) is the virulence target of several effector proteins and that its structural integrity is monitored by different $\mathrm{R}$ proteins suggests that this protein might be an ideal candidate for modification, i.e., to avoid negative interactions with the effectors.

Understanding the relative contribution of various effectors to fitness is also useful information for predicting how durable a given resistance gene might be, or for designing plant genotypes that contain optimally effective combinations of resistance genes. Kousik and Ritchie (51), for examthose pathogens cause disease on plants.

ple, used knowledge of the $X$. campestris pv. vesicatoria effector genes and their corresponding resistance genes to develop pepper lines containing combinations of defeated resistance genes with residual effects. Guided studies such as these are an important research avenue for determining the practical implications of the cost of fitness concept.

\section{Acknowledgments}

We thank Scot Hulbert, Jianfa Bai, and Kimberly Linholm for critical evaluation of the manuscript, Jennifer Foltz for help with the graphics, and C. Vera Cruz for providing photographs. This manuscript is contribution number 04-071-J from the Kansas State Agricultural Experiment Station.

\section{Notes Added in Press}

Since this article was written, the following two articles of great relevance have been published.

1. Axtell, M. J., Chisholm, S. T., Dahlbeck, D., and Staskawicz, B. 2003. Genetic and molecular evidence that the Pseudomonas syringae type III effector protein AvrRpt2 is a cysteine protease. Mol. Microbiol. 49:15371546

2. Shao, F., Golstein, C., Ade, J., Stoutemyer, M., Dixon, J. E., and Innes, R. W. 2003. Cleavage of Arabidopsis PBS1 by a bacterial type III effector. Science 301:1230-1233.

\section{Literature Cited}

1. Abramovitch, R. B., Youn-Jin, K., Shaorong, C., Dickman, M. B., and Martin, G. B. 2003. Pseudomonas type III effector AvrPtoB induces plant disease susceptibility by inhibition of host programmed cell death. EMBO J. 22:60-69.

2. Atkinson, M. M., and Baker, C. J. 1987. Association of host plasma membrane exchange with multiplication of Pseudomonas syringae pv. syringae in Phaseolus vulgaris. Phytopathology 77:1273-1279.

3. Atkinson, M. M., and Baker, C. J. 1987. Alteration of plasmalemma sucrose transport in Phaseolus vulgaris by Pseudomonas syringae pv. syringae and its association with $\mathrm{K}^{+} / \mathrm{H}^{+}$ exchange. Phytopathology 77:1573-1578.

4. Axtell, M. J., and Staskawicz, B. J. 2003. Initiation of RPS2-specified disease resistance in Arabidopsis is coupled to the AvrRpt2-directed elimination of RIN4. Cell 112:369-377.

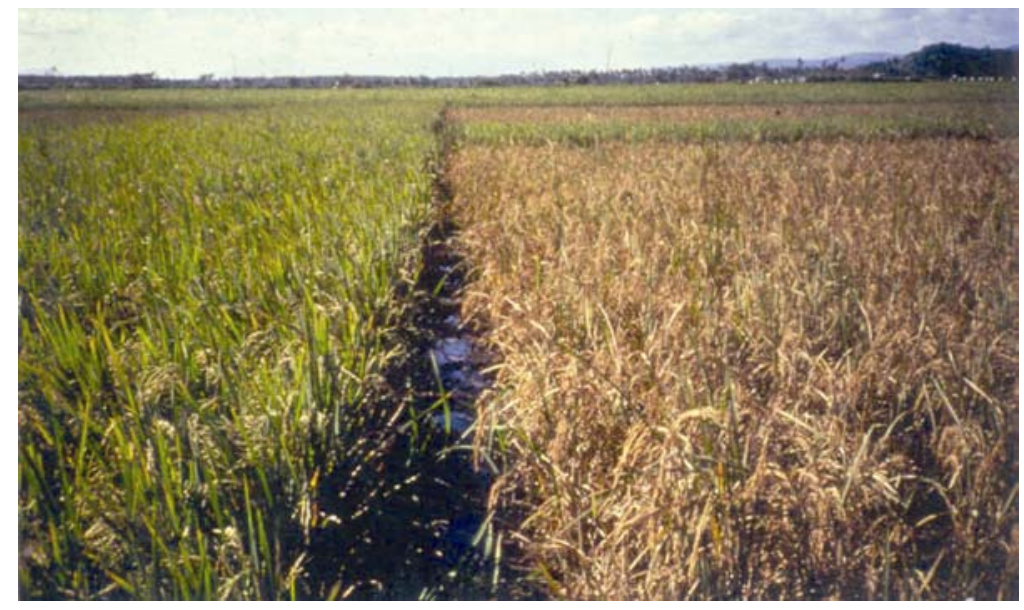

Fig. 6. Rice field in the Philippines showing resistant rice carrying the $X a 7$ bacterial blight resistance gene (cultivar IRBB7) and diseased rice lacking the $\mathrm{Xa7}$ gene (plot in right foreground, cultivar IR24, no Xa7 or Xa10; plot in right background, cultivar IRBB10 with Xa10). Photo courtesy of the International Rice Research Institute. 
5. Bai, J., Choi, S. H., Ponciano, G., Leung, H., and Leach, J. E. 2000. Xanthomonas oryzae pv. oryzae avirulence genes contribute differently and specifically to pathogen aggressiveness. Mol. Plant-Microbe Interact. 13:13221329.

6. Ballvora, A., Pierre, M., van den Ackerveken, A. G., Schornack, S., Rossier, O., Ganal, M., Lahaye, T., and Bonas, U. 2001. Genetic mapping and functional analysis of the tomato Bs4 locus governing recognition of the Xanthomonas campestris pv. vesicatoria AvrBs4 protein. Mol. Plant-Microbe Interact. 14:629638.

7. Barras, F., Van Gijsegem, F., and Chatterjee, A. K. 1994. Extracellular enzymes and pathogenesis of soft-rot Erwinia. Annu. Rev. Phytopathol. 32:201-234.

8. Bestwick, C. S., Bennett, M. H., and Mansfield, J. W. 1995. Hrp mutant of Pseudomonas syringae pv. phaseolicola induces cell wall alterations but not membrane damage leading to the HR in lettuce (Lactuca sativa). Plant Physiol. 108:503-516.

9. Blocker, A., Komoriya, K., and Aizawa, S. I. 2003. Type III secretion systems and bacterial flagella: Insights into their function from structural similarities. Proc. Natl. Acad. Sci. USA 100:3027-3030.

10. Bogdanove, A. J., Bauer, D. W., and Beer, S. V. 1998. Erwinia amylovora secretes DspE, a pathogenicity factor and functional AvrE homolog, through the hrp (type III secretion) pathway. J. Bacteriol. 80:2244-2247.

11. Bogdanove, A. J., Kim, J., Wei, Z., Kolchinsky, P., Charkowski, A. O., Conlin, A. K., Collmer, A., and Beer, S. V. 1998. Homology and functional similarity of an hrp-linked pathogenicity locus, $d s p E F$, of Erwinia amylovora and the avirulence locus avrE of Pseudomonas syringae pathovar tomato. Proc. Natl. Acad. Sci. USA 95:1325-1330.

12. Bonas, U., and Lahaye, T. 2002. Plant disease resistance triggered by pathogen-derived molecules: Refined models of specific recognition. Curr. Opin. Microbiol. 5:44-50.

13. Brown, I., Mansfield, J., and Bonas, U. 1995. hrp genes in Xanthomonas campestris pv. vesicatoria determine ability to suppress papilla deposition in pepper mesophyll cells. Mol. Plant-Microbe Interact. 8:825-836.

14. Buttner, D., and Bonas, U. 2002. Getting across-bacterial type III effector proteins on their way to the plant cell. EMBO J. 21:53135322.

15. Buttner, D., and Bonas, U. 2002. Port of entry - the type III secretion translocon. Trends Microbiol. 10:186-192.

16. Chakrabarty, P. K., Duan, Y. P., and Gabriel, D. W. 1997. Cloning and characterization of a member of the Xanthomonas avr/pth gene family that evades all commercially utilized cotton $R$ genes in the United States. Phytopathology 87:1160-1167.

17. Chang, J. H., Rathjen, J. P., Bernal, A. J., Staskawicz, B. J., and Michelmore, R. W. 2000. AvrPto enhances growth and necrosis caused by Pseudomonas syringae pv. tomato in tomato lines lacking either Pto or Prf. Mol. Plant-Microbe Interact. 13:568-571.

18. Chapon, V., Czjzek, M., El Hassouni, M., Py, B., Juy, M., and Barras, F. 2001. Type II protein secretion in gram-negative pthogenic bacteria: The study of the structure/secretion relationships of the celluslase Cel5 (formerly EGZ) from Erwinia chrysanthemi. J. Mol. Biol. 310:1055-1066

19. Chen, Z., Kloek, A. P., Boch, J., Katagirl, F., and Kunkel, B. N. 2000. The Pseudomonas syringae avrRpt 2 gene product promotes pathogen virulence from inside plant cells. Mol. Plant-Microbe Interact. 13:1312-1321.

20. Christie, P. J. 1997. Agrobacterium tumefa- ciens T-complex transport apparatus: A paradigm for a new family of multifunctional transporters in Eubacteria. J. Bacteriol. 179:3085-3094.

21. Citovsky, V., Warnick, D., and Zambryski, P. 1994. Nuclear import of Agrobacterium VirD2 and VirE2 proteins in maize and tobacco. Proc. Natl. Acad. Sci. USA 91:32103214.

22. Collmer, A. 1998. Determinants of pathogenicity and avirulence in plant pathogenic bacteria. Curr. Opin. Plant Biol. 1:329335 .

23. Cornelis, G. R. 1998. The Yersinia Deadly Kiss. J. Bacteriol. 180:5495-5504.

24. Cornelis, G. R., and Van Gijsegem, F. 2000. Assembly and function of type III secretory systems. Annu. Rev. Microbiol. 54:735-774.

25. De Feyter, R., Yang, Y., and Gabriel, D. W. 1993. Gene-for-genes interactions between cotton $R$ genes and Xanthomonas campestris pv. malvacearum avr genes. Mol. Plant-Microbe Interact. 6:225-237.

26. Flor, H. H. 1958. Mutation to wider virulence in Melampsora lini. Phytopathology 48:297301.

27. Flor, H. H. 1971. Current status of the genefor-gene concept. Annu. Rev. Phytopathol. 9:275-296.

28. Fouts, D. E., Abramovitch, R. B., Alfano, J. R., Baldo, A. M., Buell, C. R., Cartinhour, S., Chatterjee, A. K., D'Ascenzo, M., Gwinn, M. L., Lazarowitz, S. G., Lin, N. C., Martin, G. B., Rehm, A. H., Schneider, D. J., van Dijk, K., Tang, X., and Collmer, A. 2002. Genomewide identification of Pseudomonas syringae pv. tomato DC3000 promoters controlled by the HrpL alternative sigma factor. Proc. Natl. Acad. Sci. USA 99:22752280.

29. Frederick, R. D., Ahmad, M., Majerczak, D. R., Arroyo-Rodriguez, A. S., Manulis, S., and Coplin, D. L. 2001. Genetic organization of the Pantoea stewartii subsp. stewartii hrp gene cluster and sequence analysis of the $h r p A, h r p C, h r p N$, and $w t s E$ operons. Mol. Plant-Microbe Interact. 14:1213-1222.

30. Gabriel, D. W. 1999. The Xanthomonas arv/pth Gene Family. Pages 39-55 in: PlantMicrobe Interactions. G Stacey and N Keen, eds. American Phytopathological Society, St. Paul, MN.

31. Gabriel, D. W. 1999. Why do pathogens carry avirulence genes? Physiol. Mol. Plant Pathol. 55:205-124.

32. Gabriel, D. W., Yuan, Q., Yang, Y., Chakrabarty, P. K. 1996. Role of nuclear localizing signal sequences in three disease phenotypes determined by the Xanthomonas avr/pth gene family. Pages 197-202 in: Biology of PlantMicrobe Interactions. G Stacey, B Mullin, and PM Gresshoff, eds. International Society for Molecular Plant-Microbe Interactions, St. Paul, MN.

33. Galan, J. E., and Collmer, A. 1999. Type III secretion machines: Bacterial devices for protein delivery into host cells. Science 284:1322-1328.

34. Gassmann, W., Dahlbeck, D., Chesnokova, O., Minsavage, G. V., Jones, J. B., and Staskawicz, B. J. 2000. Molecular evolution of virulence in natural field strains of Xanthomonas campestris pv. vesicatoria. J. Bacteriol. 182:7053-7059.

35. Gilchrist, D. G. 1998. Programmed cell death in plant disease: The purpose and promise of cellular suicide. Annu. Rev. Phytopathol. 36:393-414.

36. Guttman, D. S., Vinatzer, B. A., Sarkar, S. F., Ranall, M. V., Kettler, G., and Greenberg, J. T. 2002. A functional screen for the type III (Hrp) secretome of the plant pathogen Pseudomonas syringae. Science 295:1722-
1726

37. Hacker, J., Hentschel, U., and Dobrindt, U. 2003. Prokaryotic chromosomes and disease. Science 301:790-793.

38. Hauck, P., Thilmony, R., and He, S. Y. 2003 A Pseudomonas syringae type III effector suppresses cell wall-based extracellular defense in susceptible Arabidopsis plants. Proc. Natl. Acad. Sci. USA 14:8577-8582.

39. He, S. Y., Huang, H. C., and Collmer, A. 1993. Pseudomonas syringae pv. syringae harpinPss: A protein that is secreted via the hrp pathway and elicits the hypersensitive response in plants. Cell 73:1255-1266.

40. Herbers, K., Conrads-Strauch, J., and Bonas, U. 1992. Race-specificity of plant resistance to bacterial spot disease determined by repetiive motifs in a bacterial avirulence protein. Nature 356:172-174.

41. Holt, B. F., Hubert, D. A., and Dangl, J. L. 2003. Resistance gene signaling in plants Complex similarities to animal innate immunity. Curr. Opin. Immunol. 15:20-25.

42. Hopkins, C. M., White, F. F., Choi, S. H., Guo, A., and Leach, J. E. 1992. Identification of a family of avirulence genes from Xanthomonas oryzae pv. oryzae. Mol. Plant-Microbe Interact. 5:451-459.

43. Hueck, C. J. 1998. Type III protein secretion systems in bacterial pathogens of animals and plants. Microbiol. Mol. Biol. Rev. 62:379433.

44. Jackson, R. W., Athanassopoulos, E., Tsiamis, G., Mansfield, J. W., Sesma, A., Arnold, D. L., Gibbon, M. J., Murillo, J., Taylor, J. D., and Vivian, A. 1999. Identification of a pathogenicity island, which contains genes for virulence and avirulence, on a large native plasmid in the bean pathogen Pseudomonas syringae pv. phaseolicola. Proc. Natl. Acad. Sci. USA 96:10875-10880.

45. Jin, Q., and He, S. Y. 2001. Role of the Hrp pilus in type III protein secretion in Pseudomonas syringae. Science 294:2556-2558.

46. Kanamori, H., and Tsuyumu, S. 1998. Comparison of nucleotide sequences of cankerforming and non-canker-forming $p t h A$ homologues in Xanthomonas campestris pv. citri. Ann. Phytopathol. Soc. Jpn. 64:462-470.

47. Kearney, B., Ronald, P. C., Dahlbeck, D., and Staskawicz, B. J. 1988. Molecular basis for evasion of plant host defense in bacterial spot disease of pepper. Nature 332:541-543.

48. Kearney, B., and Staskawicz, B. J. 1990. Widespread distribution and fitness contribution of Xanthomonas campestris avirulence gene avrBs2. Nature 346:385-386.

49. Keen, N. T. 1990. Gene-for-gene complimentary in plant-pathogen interactions. Annu. Rev. Genet. 24:447-463.

50. Kousik, C. S., and Ritchie, D. F. 1996. Race shift in Xanthomonas campestris pv. vesicatoria within a season in field-grown pepper. Phytopathology 86:952-958.

51. Kousik, C. S., and Ritchie, D. F. 1999. Development of bacterial spot on near-isogenic lines of bell pepper carrying gene pyramids composed of defeated major resistance genes. Phythopathology 89:1066-1072.

52. Leach, J. E., Vera Cruz, C. M., Bai, J. F., and Leung, H. 2001. Pathogen fitness penalty as a predictor of durability of disease resistance genes. Annu. Rev. Phytopathol. 39:187-224.

53. Lorang, J. M., and Keen, N. T. 1995. Characterization of avrE from Pseudomonas syringae pv. tomato: A hrp-linked avirulence locus consisting of at least two transcriptional units. Mol. Plant-Microbe Interact. 8:49-57.

54. Lorang, J. M., Shen, H., Kobayashi, D., Cooksey, D., and Keen, N. T. 1994. avrA and avrE in Pseudomonas syringae pv. tomato PT23 play a role in virulence on tomato plants. Mol. Plant-Microbe Interact. 7:508- 
515.

55. Mackey, D., Belkhadir, Y., Alonso, J. M., Ecker, J. R., and Dangl, J. L. 2003. Arabidopsis RIN4 is a target of the type III virulence effector AvrRpt2 and modulates RPS2-mediated resistance. Cell 112:379-389.

56. Mackey, D., Holt, B. F., Wiig, A., and Dangl, J. L. 2002. RIN4 interacts with Pseudomonas syringae type III effector molecules and is required for RPM1-mediated resistance in Arabidopsis. Cell 108:743-754.

57. Marois, E., Van den Ackerveken, G., and Bonas, U. 2002. The Xanthomonas type III effector protein AvrBs3 modulates plant gene expression and induces cell hypertrophy in the susceptible host. Mol. Plant-Microbe Interact. 15:637-646.

58. Martin, G. B., Bogdanove, A. J., and Sessa, G. 2003. Understanding the functions of plant disease resistance proteins. Annu. Rev. Phytopathol. 54:23-61

59. O'Garro, L. W., Gibbs, H., and Newton, A. 1997. Mutation in the avrBsl avirulence gene of Xanthomonas campestris pv. vesicatoria influences survival of the bacterium in soil and detached leaf tissue. Phytopathology 87:960-966.

60. Orth, K., Xu, Z., Mudgett, M. B., Bao, Z. Q., Palmer, L. E., Bliska, J. B., Mangel, W. F., Staskawicz, B., and Dixon, J. E. 2000. Disruption of signaling by Yersinia effector YopJ, a ubiquitin-like protein protease. Science 290:1594-1597.

61. Page, A. L., and Parsot, C. 2002. Chaperones of the type III pathway: Jacks of all trades. Mol. Microbiol. 46:1-11.

62. Palacios, J. L., Zaror, I., Martinez, P., Uribe, F., Opazo, P., Socias, T., Gidekel, M., and Venegas, A. 2001. Subset of hybrid eukaryotic proteins is exported by the type I secretion system of Erwinia chrysanthemi. J. Bacteriol. 183:1346-1358.

63. Petnicki-Ocwieja, T., Schneider, D. J., Tam, V. C., Chancey, S. T., Shan, L., Jamir, Y., Schechter, L. M., Janes, M. D., Buell, C. R., Tang, X., Collmer, A., and Alfano, J. R. 2002. Genomewide identification of proteins secreted by the Hrp type III protein secretion system of Pseudomonas syringae pv. tomato DC3000. Proc. Natl. Acad. Sci. USA 99:76527657.

64. Pugsley, A. P. 1993. The complete general protein secretion pathway in Gram-negative bacteria. Microbiol. Rev. 57:50-108.

65. Reuber, T. L., and Ausubel, F. M. 1996. Isolation of Arabidopsis genes that differentiate between resistance responses mediated by the RPS2 and RPM1 disease resistance genes. Plant Cell 8:241-249.

66. Ritter, C., and Dangl, J. L. 1995. The avrRpm1 gene of Pseudomonas syringae pv. maculicola is required for virulence on Arabidopsis. Mol. Plant-Microbe Interact. 8:444453.

67. Ritter, C., and Dangl, J. L. 1996. Interference between two specific pathogen recognition events mediated by distinct plant disease resistance genes. Plant Cell 8:251-257.

68. Salmond, G. P. C., and Reeves, P. J. 1994. Secretion of extracellular virulence factors by plant pathogenic bacteria. Annu. Rev. Phytopathol. 32:181-200.

69. Scofield, S. R., Tobias, C. M., Rathjen, J. P., Chang, J. H., Lavelle, D. T., Michelmore, R. W., and Staskawicz, B. J. 1996. Molecular basis of gene-for-gene specificity in bacterial speck disease of tomato. Science 274:20632065.

70. Shan, L., He, P., Zhou, J. M., and Tang, X. 2000. A cluster of mutations disrupt the avirulence but not the virulence function of AvrPto. Mol. Plant-Microbe Interact. 13:592-598.

71. Shao, F., Merritt, P. M., Bao, Z., Innes, R. W.,

and Dixon, J. E. 2002. A Yersinia effector and a Pseudomonas avirulence protein define a family of cysteine proteases functioning in bacterial pathogenesis. Cell 109:575-588.

72. Shiraishi, T., Toyoda, K., Yamada, T., Ichi-

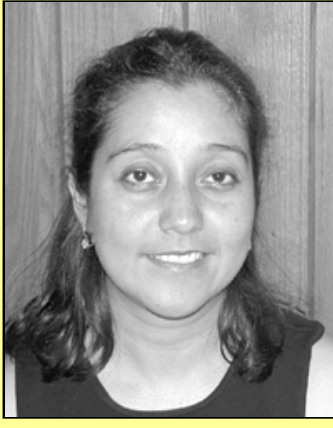

Grisel Ponciano

Ms. Ponciano is a graduate student in the Department of Plant Pathology at Kansas State University working toward her Ph.D. in plant pathology. She received her B.S. degree in biochemistry from Universidad del Valle de Guatemala. She studies the molecular evolution of avirulence effector genes from Xanthomonas oryzae pv. oryzae in field populations. She and Dr. Leach have collaborated with Dr. Tsuyumu and Mr. Ishihara for the past 2 years on a functional analysis of avrBs3/pthA family members from $X$. oryzae pv. oryzae and $X$. axonopodis pv. citri.

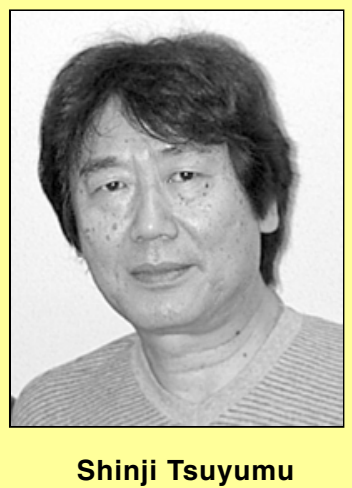

Dr. Tsuyumu is a professor in the Laboratory of Plant Pathology, Faculty of Agriculture, Shizuoka University, Japan. He received his B.S. from Shizuoka University. His M.A. and Ph.D. are in microbiology from U.C. Davis and the University of Hawaii, respectively. After a postdoctoral position in H. E. Umbarger's lab in the Department of Biological Sciences at Purdue University, he joined the faculty of Shizuoka University, where he started the work on the regulatory mechanism of pectinases in soft-rot Erwinia spp. and the interactions between the citrus canker pathogen, Xanthomonas axonopodis pv. citri, and host and nonhost plants. nose, Y., Kiba, A., and Sugimoto, M. 2001 Suppressors of defense-Supprescins and plant receptor molecules. Pages 112-121 in: Delivery and Perception of Pathogen Signals in Plants. N. T. Keen, S. Mayama, J. E. Leach,

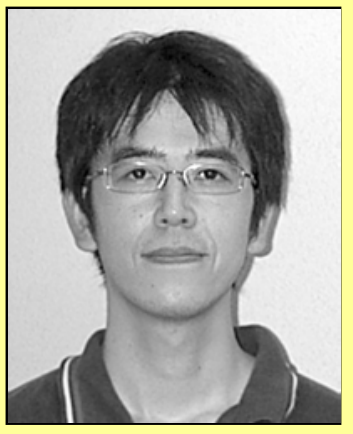

Hiromichi (Hiro) Ishihara

Mr. Ishihara is a graduate student working to earn his Ph.D. in Dr. Tsuyumu's lab in the Laboratory of Plant Pathology, Faculty of Agriculture, Shizuoka University, Japan. He received his B.S. degree from Shizuoka University. His research involves determining critical features of the avrBs3/pthA effector gene family members that govern function in avirulence and virulence to citrus, rice, and other host plants. He also studies a gene isolated from Xanthomonas axonopodis pv. citri that contributes to in planta growth. Mr. Ishihara joined Dr. Leach's laboratory for 3 months in 2001 to initiate the collaboration between the labs.

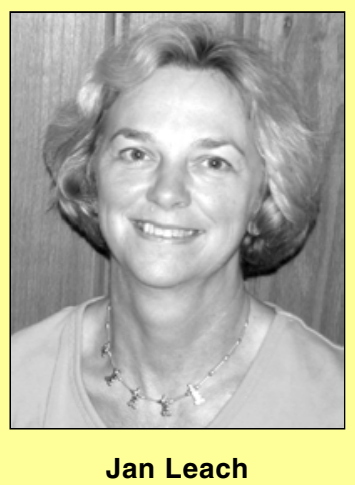

Dr. Leach is a professor at Kansas State University and an adjunct scientist at the International Rice Research Institute in the Philippines. She received her B.S. and M.S. degrees in microbiology from the University of Nebraska-Lincoln and her Ph.D. from the University of Wisconsin-Madison. After a postdoctoral position at East Malling Research Station, Kent, England, Dr. Leach joined the faculty at KSU where she began her studies of the interactions between the bacterial blight pathogen, Xanthomonas oryzae pv. oryzae, and rice. 
and S. Tsuyumu, eds. American Phytopathological Society, St. Paul, MN.

73. Staskawicz, B., Dahlbeck, D., and Keen, N. T. 1984. Cloned avirulence gene of Pseudomonas syringae pv. glycinea determines racespecific incompatiblity on Glycines $\max (\mathrm{L}$.) Merr. Proc. Natl. Acad. Sci. USA 81:60246028.

74. Swarup, S., De Feyter, R., Brlansky, R. H., and Gabriel, D. W. 1991. A pathogenicity locus from Xanthomonas citri enables strains from several pathovars of $X$. campestris to elicit cankerlike lesions on citrus. Phytopathology 81:802-809.

75. Swarup, S., Yang, Y., Kingsley, M. T., and Gabriel, D. W. 1992. A Xanthomonas citri pathogenicity gene, pthA, pleiotropically encodes gratuitous avirulence on nonhosts. Mol. Plant-Microbe Interact. 5:204-213.

76. Swords, K. M. M., Dahlbeck, D., Kearney, B., Roy, M., and Staskawicz, B. J. 1996. Spontaneous and induced mutations in a single open reading frame alter both virulence and avirulence in Xanthomonas campestris pv. vesicatoria avrBs2. J. Bacteriol. 178:46614669.

77. Szurek, B., Marois, E., Bonas, U., and Van den Ackerveken, G. 2001. Eukaryotic features of the Xanthomonas type III effector AvrBs3: Protein domains involved in transcriptional activation and the interaction with nuclear import receptors from pepper. Plant J. 26:523534
78. Szurek, B., Rossier, O., Hause, G., and Bonas, U. 2002. Type III-dependent translocation of the Xanthomonas AvrBs3 protein into the plant cell. Mol. Microbiol. 46:13-23.

79. Tang, X., Xie, M., Kim, Y. J., Zhou, J., Klessig, D. F., and Martin, G. B. 1999. Overexpression of Pto activates defense responses and confers broad resistance. Plant Cell 11:15-29.

80. Tsiamis, G., Mansfield, J. W., Hockenhull, R., Jackson, R. W., Sesma, A., Athanassopoulos, E., Bennett, M. A., Stevens, C., Vivian, A., Taylor, J. D., and Murillo, J. 2000. Cultivarspecific avirulence and virulence functions assigned to avrPphF in Pseudomonas syringae pv. phaseolicola, the cause of bean haloblight disease. EMBO J. 19:3204-3214.

81. Van den Ackerveken, G., Marois, E., and Bonas, U. 1996. Recognition of the bacterial avirulence protein AvrBs3 occurs inside the host plant cell. Cell 87:1307-1316.

82. Van der Plank, J. E. 1978. Genetic and Molecular Basis of Plant Pathogenesis. SpringerVerlag, Berlin.

83. Vera Cruz, C. M., Bai, J., Oña, I., Leung, H., Nelson, R. J., Mew, T. W., and Leach, J. E. 2000. Predicting durability of a disease resistance gene based on an assessment of the fitness loss and epidemiological consequences of avirulence gene mutation. Proc. Natl. Acad. Sci. USA 97:13500-13505.

84. White, F. F., Yang, B., and Johnson, L. B. 2000. Prospects for understanding avirulence gene function. Curr. Opin. Plant Biol. 3:291298.

85. Yang, B., Zhu, W., Johnson, L. B., and White, F. F. 2000. The virulence factor AvrXa7 of Xanthomonas oryzae pv. oryzae is a type III secretion pathway-dependent, nuclear-localized, double-stranded DNA binding protein. Proc. Natl. Acad. Sci. USA 97:9807-9812.

86. Yang, Y., and Gabriel, D. W. 1995. Xanthomonas avirulence/pathogenicity gene family encodes functional plant nuclear targeting signals. Mol. Plant-Microbe Interact. 8:627-631.

87. Yang, Y., Yuan, Q., and Gabriel, D. W. 1996. Watersoaking function(s) of $\mathrm{XcmH} 1005$ are redundantly encoded by members of the Xanthomonas avr/pth gene family. Mol. Plant-Microbe Interact. 9:105-113.

88. Yucel, I., Slaymaker, D., Boyd, C., Murillo, J., Buzzell, R. I., and Keen, N. T. 1994. Avirulence gene avrPphC from Pseudomonas syringae pv. phaseolicola 3121: A plasmidborne homologue of $a v r C$ closely linked to an avrD allele. Mol. Plant-Microbe Interact. 7:677-679.

89. Zhang, Y., Bak, D. D., Heid, H., and Geider, K. 1999. Molecular characterization of a protease secreted by Erwinia amylovora. J. Mol. Biol. 289:1239-1251.

90. Zhu, W., Yang, B., Chittoor, J. M., Johnson, L. B., and White, F. F. 1998. AvrXa10 contains an acidic transcriptional activation domain in the functionally conserved $\mathrm{C}$ terminus. Mol. Plant-Microbe Interact. 11:824-832. 